\title{
Reconstructing flow paths of the Middle Pleistocene British Ice Sheet in central-eastern England: the application of regional soil geochemical data
}

\author{
Andreas J. Scheib*, Jonathan R. Lee, Neil Breward, James B. Riding \\ British Geological Survey, Kingsley Dunham Centre, Keyworth, Nottingham, NG12 5GG, UK
}

A R T I C L E I N F O

Article history:

Received 28 September 2010

Received in revised form 20 January 2011

Accepted 24 January 2011

Available online $\mathrm{xxx}$

\section{Keywords:}

Quaternary

Tills

East Anglia

Provenancing

Geochemical signatures

\begin{abstract}
A B S T R A C T
High-density regional geochemical data for surface soils in central England and East Anglia reveal that much of their geochemical character is inherited from the tills that they are developed upon. Multivariate statistical analysis highlighted three significant element associations of $\mathrm{Al}-\mathrm{Fe}-\mathrm{Ga}-\mathrm{K}-\mathrm{La}-$ $\mathrm{Mg}-\mathrm{Rb}, \mathrm{Ca}-\mathrm{Sr}$ and $\mathrm{K}-\mathrm{Fe}$ accounting for almost $93 \%$ of the geochemical variability of soils derived from tills. Provenancing the geochemical signatures of the latter elements enabled the construction of ice flow paths associated with two different Middle Pleistocene 'chalky' till sheets. A lower till sheet relating to 'Pennine' ice flowing from west to east across the region, and an upper till sheet deposited by North Sea ice moving into northern East Anglia, and to the west of the Fen Basin, before fanning-out across central England. Overall, geochemical signatures of different till units are largely derived from local bedrock sources, with dilution and a new geochemical signature acquired as the ice flows over and incorporates new bedrock lithologies. The results show that high resolution soil geochemical data provides a further proxy with which the flow paths of former ice sheets can be delineated.
\end{abstract}

(c) 2011 Published by Elsevier Ltd on behalf of The Geologists' Association.

\section{Introduction}

Reconstructing the extent and dynamics of Quaternary glaciations can, along with an awareness of the relative chronology, provide a detailed insight into the glaciology of former ice masses. This plays a crucial role in enhancing our understanding of how ice masses behave relative to different boundary conditions, and ultimately, how they interact with other earth systems and climate change (Benn and Evans, 1998).

Determining the glaciology of former ice masses relies upon the interpretation of landforms and sediments preserved within the geological record. However, a significant challenge of working with these data is gathering a sufficient volume and spatial spread of data to provide a regional-scale perspective of the ice mass (Straw, 1983). Several research programs have addressed this by collecting large regional to national scale landform data sets via Digital Terrain Models and offshore bathymetry data. Such an approach has been applied to the British and Irish ice sheets during the Last Glacial Maximum (Clark et al., 2004, 2010; Bradwell et al., 2008; Greenwood and Clark, 2008), as well as sectors of the Scandinavian Ice Sheet (e.g. Kalm, in press). Another approach is to examine spatial variations in the composition and provenance of regionally

\footnotetext{
* Corresponding author. Tel.: +44 115 9363100; fax: +44 1159363264.

E-mail address: ascheib@bgs.ac.uk (A.J. Scheib).
}

extensive till sheets in order to reconstruct former ice flow paths (Clark, 1987; Larson and Mooers, 2005). This approach requires a high density and systematic distribution of data points, and has been applied widely for drift prospecting in mid- and high-latitude regions formerly glaciated by the Laurentide and Scandinavian Ice Sheets (McClenaghan et al., 1992; Klassen, 2001; Lehoten et al., 2005; Sarala, 2005).

Within the British Isles, Perrin et al. (1979) employed a similar approach utilising calcium carbonate, heavy mineral and particle size data from a Middle Pleistocene till sheet to develop a flow model for the British Ice Sheet in central England and East Anglia. Although this model has subsequently been elaborated by the addition of new data (Rose, 1989, 1992), geological mapping and site investigations have suggested that two (rather than one) laterally persistent till sheets may be present across central England and East Anglia (Hamblin et al., 2005; Rose, 2009; Lee et al., in press). Furthermore the original model has been questioned by several other studies (e.g. Straw, 1983; Fish et al., 2000; Fish and Whiteman, 2001). The purpose of this paper is to reconstruct an ice flow model in central England and East Anglia relative to the new stratigraphic succession. To achieve this, we employ high-resolution regional-scale geochemical data obtained from soils developed on tills (Scheib et al., 2009a,b), to reconstruct ice flow paths responsible for depositing the tills. Geochemical data has not previously been used at such a large spatial scale to resolve Quaternary geological issues within Britain. The application of the technique within this study - principally as a

0016-7878/\$ - see front matter (c) 2011 Published by Elsevier Ltd on behalf of The Geologists' Association.

doi:10.1016/j.pgeola.2011.01.008 
stand-alone proxy, highlights the value of such data in stratigraphic studies.

\section{Location, stratigraphy and models of glaciation}

\subsection{Location and models of glaciation}

The study area covers all of East Anglia and extends into central England as far west as Birmingham (Fig. 1). The dataset has been cropped to the south using the Anglian ice limit defined by Clark et al. (2004), and the Devensian ice limit in Norfolk and the West Midlands (Clark et al., 2003; Pawley et al., 2006). The study area is covered extensively by tills deposited in association with the British Ice Sheet during the Middle Pleistocene. However, the precise number of glaciations and their associated flow paths have historically generated considerable controversy (West and Donner, 1956; Catt, 1979; Perrin et al., 1979; Straw, 1983; Preece et al., 2009; Rose, 2009).

Structural measurements collected by West and Donner (1956) led them to infer two separate ice advances across central England and East Anglia during the Middle Pleistocene associated with 'chalky till' (Fig. 2). This model proposed an initial advance from the west that deposited a Jurassic-rich ('Lowestoft') till facies. A second, later advance from the north deposited a chalk-rich ('Gipping') till facies. By contrast, investigations by Perrin et al. (1979) argued that these Jurassic- and chalk-rich tills formed a single continuous chalky till sheet reflecting differential incorporation of bedrock lithologies into the subglacial bed by ice fanning outwards from the Fen Basin. Evidence from other studies also supported this model (e.g. Kelly and Rawson, 1983; Mathers et al.,
1987), although it was later refined by Rose (1992) to take into consideration evidence for an earlier advance of Pennine ice from the west represented by the Thrussington Till of Shotton (1983). The Perrin et al. model (and by inference that of Rose (1992)) was challenged by Straw (1983) who argued, based upon lithological and geomorphological evidence, for North Sea ice extending south and eastwards across the Lincolnshire Wolds rather than being restricted to present North Sea coastal areas. Subsequent studies by Fish et al. (2000) and Fish and Whiteman (2001) utilise chalk microfossils to provenance the chalky tills. They concur in-part with Straw's model with the idea of southwards flowing ice extending across the Lincolnshire and Yorkshire Wolds and also speculate on the role played by the Scandinavian Ice Sheet in controlling the dynamics of the British Ice Sheet.

\subsection{Stratigraphy}

Whilst each of the models outlined in the previous section utilise different and novel investigative approaches, their integrity is to a large extent determined by the relative stratigraphic frameworks of the till units. There are three specific stratigraphic problems within the study area: (1) major lithological differences exist in the composition of Jurassic-rich tills in central England; (2) satisfactory correlation of tills between central England and East Anglia has proved tenuous due to the absence or limited surface exposure of tills around the Fen Basin and adjacent Chalk escarpment; (3) the stratigraphic relationship between the "chalky till' of central East Anglia, and the sandy tills of north Norfolk has proved difficult to define.

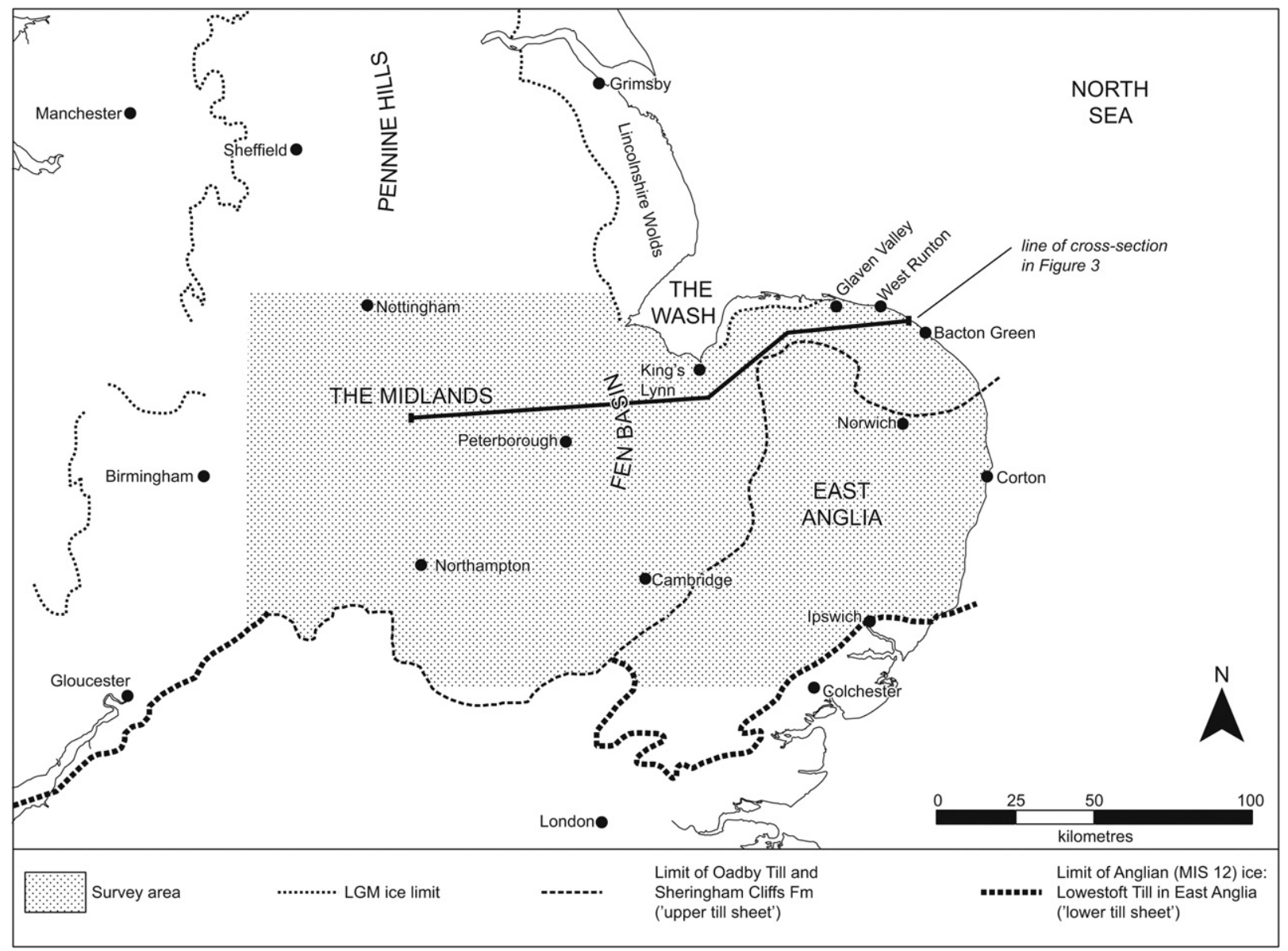

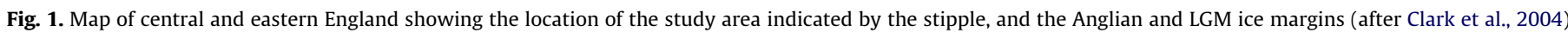



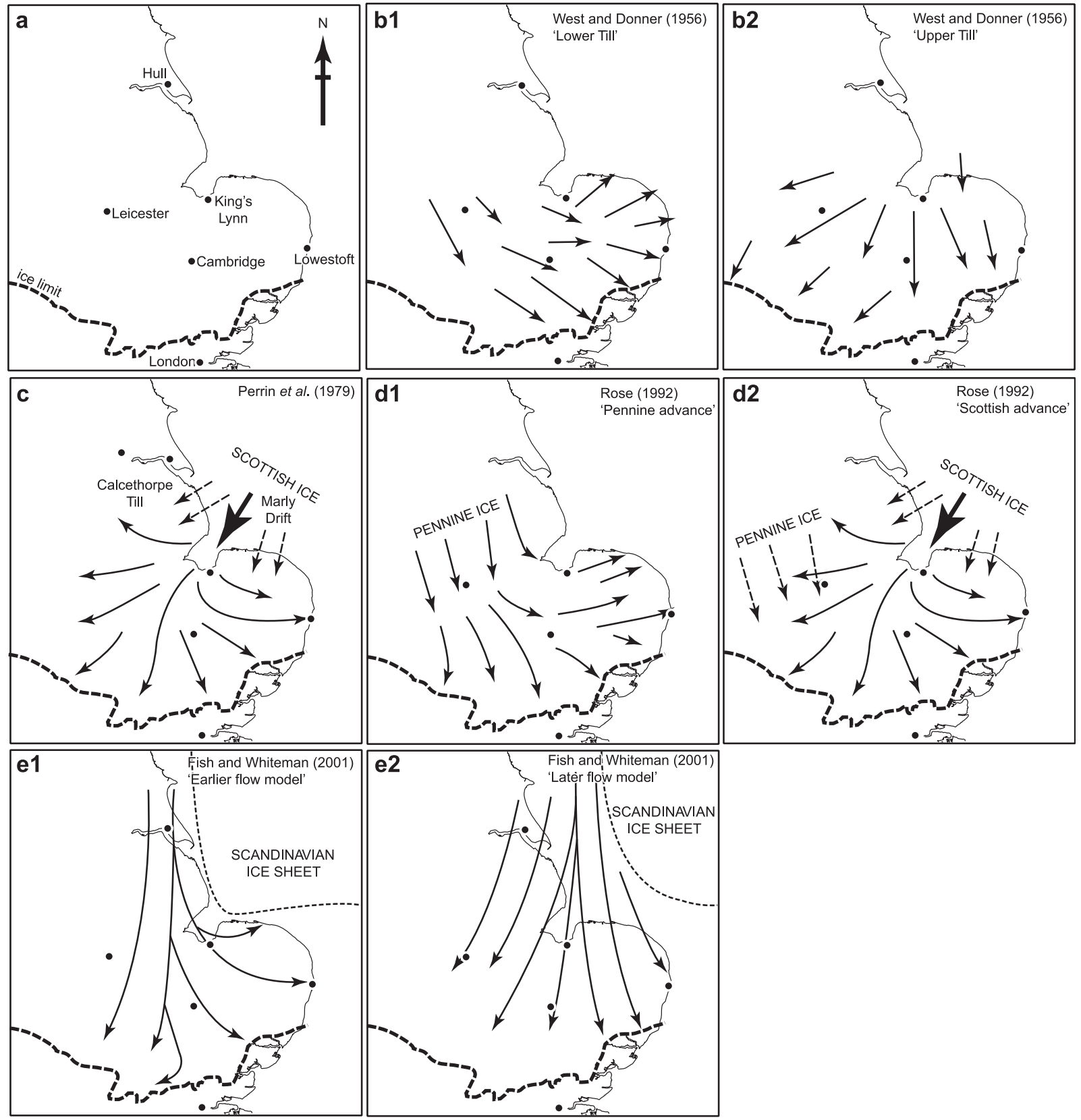

Fig. 2. Previously published ice flow scenarios for the chalky tills of East Anglia and central England. (a) Geographic map; (b) ice flow model of West and Donner (1956) based on structural measurements including an (b1) early advance from the west depositing the 'lower till' and (b2), a later advance of North Sea ice from the north depositing a highly calcareous 'upper till'; (c) ice flow model of Perrin et al. (1979) based upon till matrix properties of surface till samples, showing the flow of Scottish ice through the Wash Basin and its fanning-out over eastern England; (d) an evolution to the Perrin et al. model presented by Rose (1992) that incorporates the Triass-rich tills of the West Midlands - an earlier advance of Pennine ice from the west (d1), followed by a later advance of Scottish ice through the Wash Basin; (e) ice flow model of Fish and Whiteman (2001) based upon the provenancing of micro-fossils from calcareous clasts and the till matrix - an earlier north-south advance (e1) with mainly terrestrial ice, and a later north-south (e2) with the focus of ice moving eastwards into the North Sea associated with the retreat of the Scandinavian Ice Sheet.

Recent geological mapping and examination of boreholes drilled for aggregate prospecting, enhanced our understanding of the geometric arrangement of major till bodies across central England and East Anglia. The stratigraphy employed within this paper is based upon these studies and is summarised below and recognises two laterally persistent till sheets across the study area (Fig. 3).

The 'lower till sheet' can be traced across much of central England and East Anglia, although its surface outcrop in central England and northern East Anglia is limited. The till sheet comprises three separate till units - the Thrussington Till (TTM), the Bozeat Till (BTM) and the Lowestoft Till (LTM) members.
Throughout central England and the Fen Basin, much of this till sheet (the TTM and BTM) which is chalk-free, is concealed beneath younger Pleistocene (i.e. the 'upper till sheet') and subsequent Holocene deposits, and has a limited outcrop along the flanks of major river valleys (Rice, 1968; Evans, 1975; Shotton, 1983; Gallois, 1994; Barron et al., 2006; Carney and Ambrose, 2007). Few sample points are available from soils developed on these tills. Where the 'lower till sheet' extends into southern and central East Anglia it is frequently observed at surface as the Lowestoft Till Member (LTM) (Hopson and Bridge, 1987; Allen et al., 1991; Rose, 1992; Moorlock et al., 2000). The LTM possesses a highly variable lithology. At its stratotype locality at Corton in East Anglia the LTM 

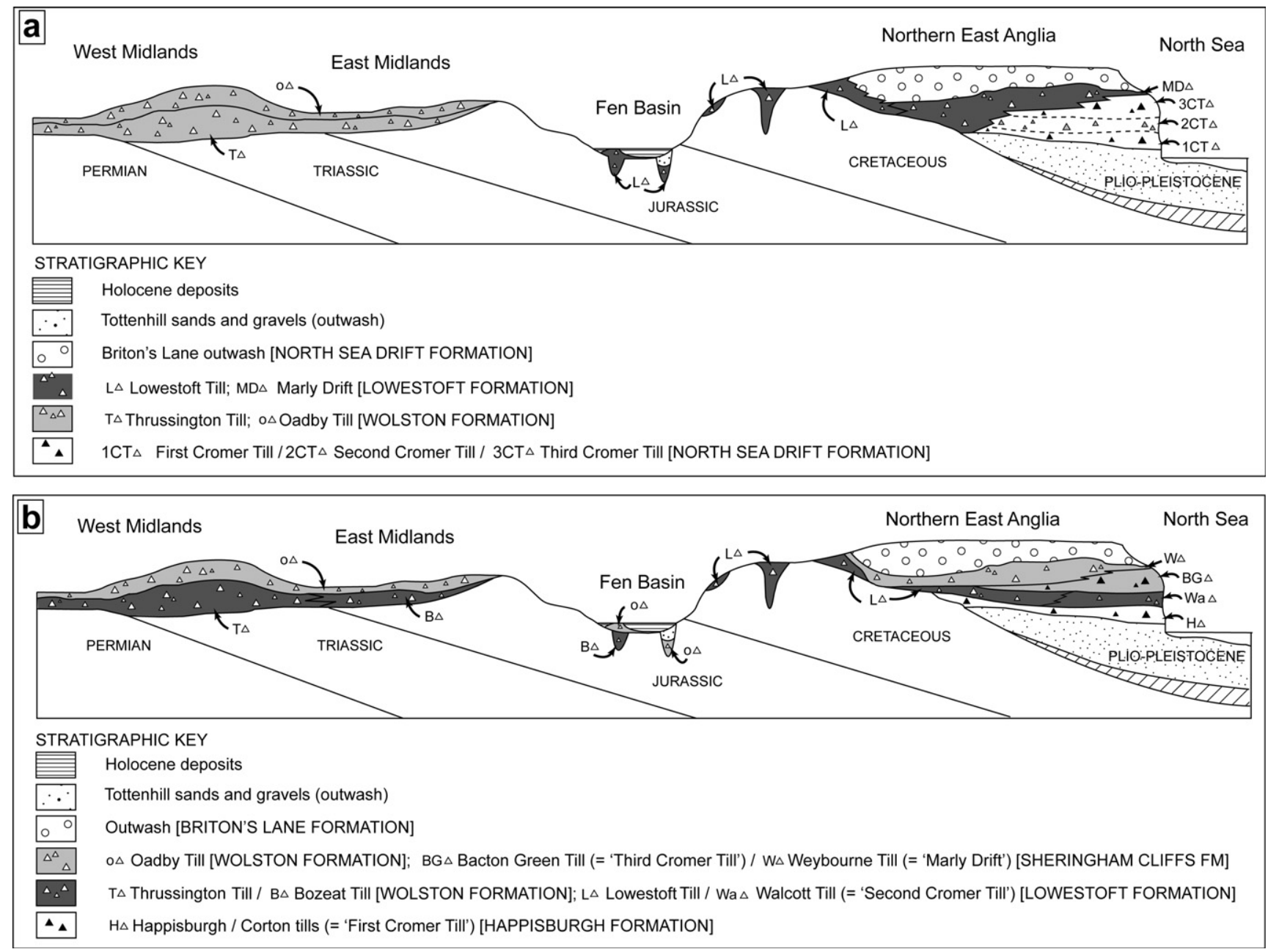

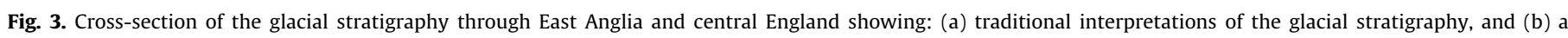
reinterpretation of the glacial stratigraphy showing the 'upper' (light grey) and 'lower' (dark grey) till sheets (from Lee et al., in press).

comprises a dark grey till rich in Late Jurassic (Kimmeridgian) clay, with abundant flint and chalk from Late Cretaceous bedrock (Baden-Powell, 1948; Pointon, 1978). Elsewhere, across southern and central East Anglia, the Lowestoft Till has a more varied local appearance reflecting differential incorporation of Pleistocene sand and gravel, Jurassic mudstone and Cretaceous chalk (Perrin et al., 1979; Hart et al., 1990; Allen et al., 1991).

The 'upper till sheet' crops-out extensively across central England and northern East Anglia and forms the principal focus of this paper due to the greater spatial availability of associated soil sample data. In central England, this till sheet comprises the widespread Oadby Till Member (OTM) and its local equivalents (Straw, 1983; Bowen, 1999). The OTM exhibits a variable lithology reflecting differential incorporation of localised Carboniferous, Triassic and Jurassic limestone, sandstone and mudstone lithologies (Rice, 1968; Riding, 2004). A distinctive lithological trait of the OTM is the occurrence of significant proportions of Cretaceous Chalk clasts (Rice, 1968). Beyond the Fen Basin, the OTM passes east- and northwards into the Weybourne Town Till Member (WTTM; formerly 'Marly Drift') that crops-out in north-western and northern East Anglia. The till composition changes broadly eastwards from being a Chalk and Jurassic mudstone dominated till, to a till dominated exclusively by comminuted chalk with local inclusions of older sandy till (Banham and Ranson, 1965; Ehlers et al., 1987; Perrin et al., 1979; Riding, 2001; Pawley et al., 2004; Hart, 2007). Critically, the WTTM does not possess any Triassic material either as clasts or derived microfossils.

\section{Methodology}

\subsection{Sampling, preparation and analysis}

Soil samples within the study area were collected as part of the British Geological Survey's G-BASE (Geochemical Baseline of the Environment) project between 1997 and 2004. The survey covered central England and East Anglia extending across ca. 26,000 km². Over 13,000 sites were visited at an average sampling density of 1 site per $2 \mathrm{~km}^{2}$ (Johnson et al., 2005). At each site two samples were collected corresponding to 'surface soil' (5-20 cm depth) and 'profile soil' (35-50 cm depth). Each sample consisted of a composite of five sub-samples collected at the corners and centre of a $20 \mathrm{~m}$ square, and were collected using a hand-held Dutch soil auger. Site information including land-use, soil texture, simplified colour codes, soil moisture content and organic matter content were also collected and form part of the G-BASE dataset (Johnson et al., 2005).

Samples were subsequently transported to laboratories at the BGS in Keyworth, Nottingham where individual soil samples were dried and sieved to extract the $<2 \mathrm{~mm}$ fraction, sub-sampled and pulverised in agate ball mills, and finally pelletised. Up to 53 major and trace elements were determined by wavelength (WD) and energy dispersive (ED) X-ray fluorescence spectrometry (XRFS) (Ingham and Vrebos, 1994). Duplicate samples and reference materials were included within every batch of 100 analysed samples to monitor and maintain precision and accuracy of all data (Johnson et al., 2008). 


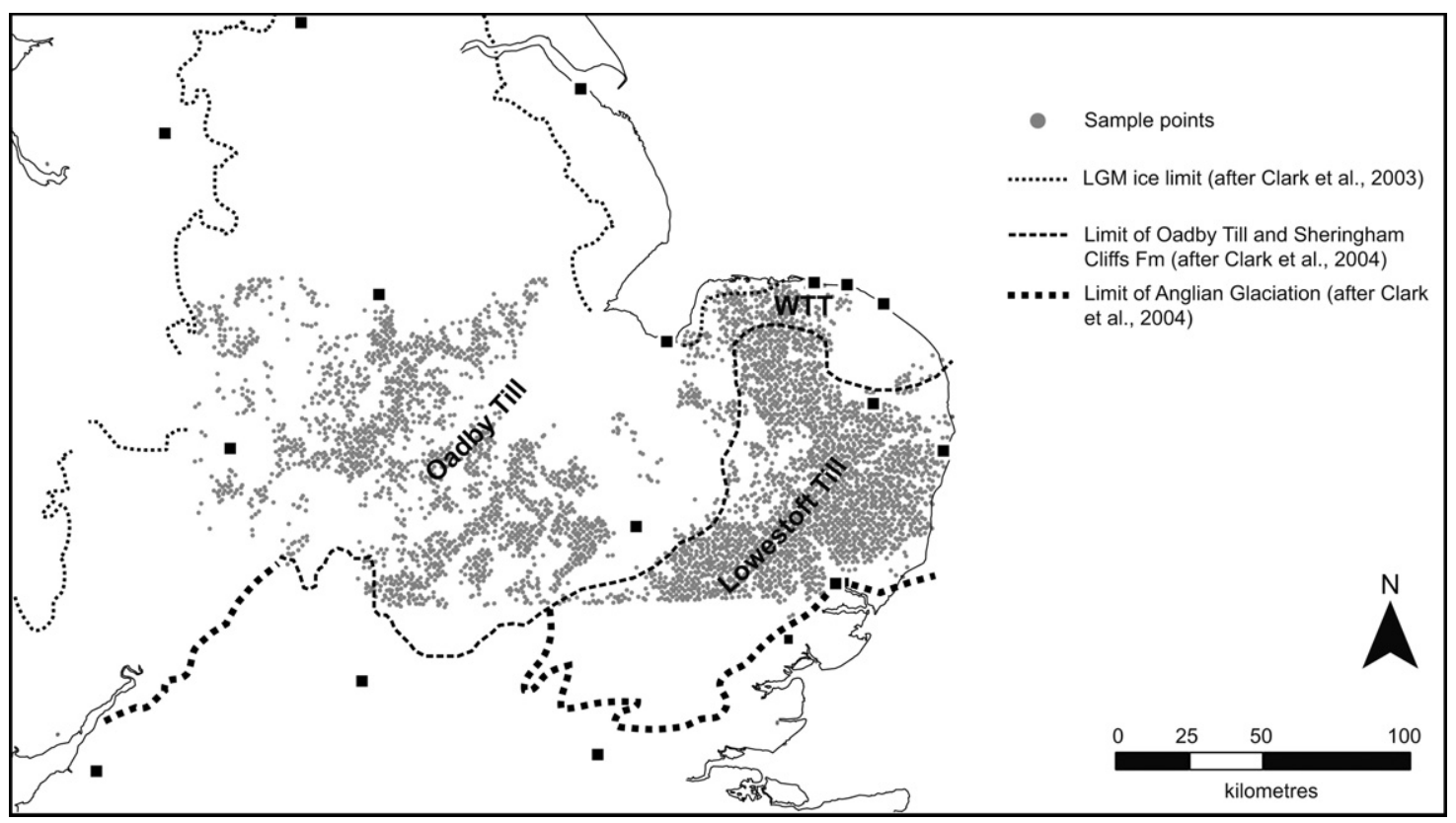

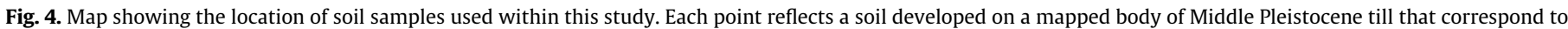
either the 'lower' till sheet (Lowestoft Till) or the 'upper' till sheet (Oadby Till and WTT - Weybourne Town Till).

\subsection{Data preparation}

This study used only surface soil data because (1) of the availability of data across the whole study area, and because (2) a preliminary study demonstrated that the bulk geochemical signature is largely inherited from the underlying geology and evident throughout the soil profile (Scheib et al., 2009a). Initially the whole dataset of 53 elements was reduced by multivariate analysis to identify the statistically significant geochemical elements (Scheib et al., 2009a). Other geochemical elements, although highlighted as being statistically significant, were removed from the dataset. This included hafnium (Hf) and zirconium $(\mathrm{Zr})$, for which elevated concentrations in soils are the product of Late Pleistocene and Holocene aeolian processes (Scheib and Lee, 2010); some base metals such as lead (Pb) and zinc $(\mathrm{Zn})$ as well as phosphorous $(\mathrm{P})$ which may be naturally occurring but could also be derived from anthropogenic sources; and some of the rare earth elements (REE) on the basis of detection limit issues. The derived geochemical data contains nine geochemical elements: aluminium ( $\mathrm{Al})$, calcium (Ca), iron (Fe), gallium ( $\mathrm{Ga})$, potassium (K), lanthanum ( $\mathrm{La})$, magnesium (Mg), strontium ( $\mathrm{Sr}$ ) and rubidium $(\mathrm{Rb})$ (Scheib et al., 2009a).

In addition to limiting the dataset to the most significant indicator elements, a spatial join between the latter and the spatial distribution of till deposits at 1:50,000 scale was carried out to only retain sample points in the dataset that are situated on Middle Pleistocene tills determined from geological mapping - reflecting 4187 samples or $32 \%$ of the original dataset (Fig. 4). These remaining data points therefore reflect the upper most surface outcrop of mapped till units. Units that occur at depth or have limited spatial outcrop are not included within the dataset. This included much of the Thrussington Till in central England, and the Happisburgh, Walcott and Bacton Green Tills in northern East Anglia.

A second dataset comprising sample points excluded by the above spatial join was also created. This dataset represents soil samples which are not located over Quaternary deposits and represent the underlying bedrock lithologies. The latter were used to determine the geochemical signature of the primary bedrock units in East Anglia and central England.

\subsection{Multivariate analysis of geochemical data}

Principal component analysis (PCA) was chosen to examine the interrelation and associations of elements within the surface soil data. PCA is a multivariate statistical technique that has been widely used in regional geochemistry (Grunsky and Smee, 1999; Cheng et al., 2006; Reimann et al., 2008; Scheib et al., 2009a,b) and Quaternary studies to identify key variables within a dataset, and to determine how different variables inter-relate (Gibbard, 1986; Kovach, 1995; Richards, 1998, 2002; Lee, 2003; Davies et al., 2009).

It is well established that regional-scale geochemical data seldom display a normal distribution (Reimann and Filzmoser, 2000). However, PCA is based on a correlation matrix which is strongly affected by non-normally distributed data and outliers (Reimann et al., 2008). Consequently, all of the geochemical data used within this study were log-transformed prior to the analysis. PCA calculates two statistics based on a varimax rotation and correlation matrix method. Firstly, eigenvectors (or 'principal component coefficients') which are loadings that describe the relative significance of a component (e.g. major or trace elements) and its geochemical variability within a dataset. Secondly, eigenvalues (or 'principal component scores') which provide percentage values for the total variance and importance of each component within a dataset.

\section{Results}

\subsection{Summary statistics}

Table 1 summarises descriptive statistics of $\mathrm{Al}, \mathrm{Ca}, \mathrm{Fe}, \mathrm{Ga}, \mathrm{K}$, $\mathrm{Mg}, \mathrm{La}, \mathrm{Sr}$ and $\mathrm{Rb}$ concentrations in surface soils developed on till. Concentration levels of the main mineral forming elements $\mathrm{Al}$, $\mathrm{Ca}, \mathrm{Fe}, \mathrm{K}$ and $\mathrm{Mg}$ show that the geochemical composition of the soils is highly variable with a wide data spread and very high values for Ca and Fe in some soils (up to $18 \%$ ). The geochemical data of $\mathrm{Ca}$ and $\mathrm{Sr}$ shows a strong positive skewness with values of 3.3 and 2.2 respectively, which is an indication of non-normally distributed data. 
Table 1

Descriptive statistics for $\mathrm{Al}, \mathrm{Ca}, \mathrm{Fe}, \mathrm{Ga}, \mathrm{K}, \mathrm{La}, \mathrm{Mg}, \mathrm{Rb}$ and $\mathrm{Sr}$ (in mg/kg) in surface soils collected over Middle Pleistocene tills.

\begin{tabular}{|c|c|c|c|c|c|c|}
\hline \multirow[t]{2}{*}{ Variables } & \multicolumn{6}{|c|}{ Descriptive statistics $(n=4195)$} \\
\hline & Min & Max & Mean & Median & StDev & Skewness \\
\hline $\mathrm{Al}$ & 0.0 & 98,923 & 47,449 & 48,668 & 15,437 & -0.29 \\
\hline $\mathrm{Ca}$ & 0.0 & 183,178 & 15,363 & 7147 & 21,647 & 3.3 \\
\hline $\mathrm{Fe}$ & 0.0 & 185,341 & 27,972 & 27,347 & 11,302 & 1.5 \\
\hline $\mathrm{Ga}$ & 0.1 & 22.4 & 9.4 & 9.5 & 3.4 & -0.03 \\
\hline $\mathrm{K}$ & 2988 & 29,137 & 13,169 & 13,282 & 2912 & 0.24 \\
\hline $\mathrm{La}$ & 3.0 & 108.6 & 27.1 & 27.0 & 7.9 & 0.29 \\
\hline $\mathrm{Mg}$ & 603 & 24,727 & 4,619 & 4,825 & 2,484 & 0.26 \\
\hline $\mathrm{Rb}$ & 2.0 & 161.0 & 73.7 & 76.0 & 22.6 & -0.24 \\
\hline $\mathrm{Sr}$ & 16.0 & 307.0 & 69.8 & 62.0 & 30.9 & 2.2 \\
\hline
\end{tabular}

Table 2

Results of PCA of log-transformed G-BASE surface soil data for elements $\mathrm{Al}, \mathrm{Ca}, \mathrm{Fe}$, $\mathrm{Ga}, \mathrm{K}, \mathrm{La}, \mathrm{Mg}, \mathrm{Rb}$ and $\mathrm{Sr}$ including eigenvalues and variance $(n=4187)$.

\begin{tabular}{lccc}
\hline Variables & \multicolumn{2}{l}{ Principal components } & \multicolumn{1}{c}{ PC3 } \\
\cline { 2 - 4 } & PC1 & PC2 & -0.024 \\
\hline $\mathrm{Al}$ & 0.363 & -0.172 & 0.127 \\
$\mathrm{Ca}$ & 0.190 & 0.766 & -0.612 \\
$\mathrm{Fe}$ & 0.341 & -0.072 & -0.075 \\
$\mathrm{Ga}$ & 0.370 & -0.119 & 0.681 \\
$\mathrm{~K}$ & 0.322 & -0.228 & -0.313 \\
$\mathrm{La}$ & 0.365 & 0.037 & 0.147 \\
$\mathrm{Mg}$ & 0.345 & -0.133 & 0.101 \\
$\mathrm{Rb}$ & 0.365 & -0.173 & 0.096 \\
$\mathrm{Sr}$ & 0.300 & 0.514 & 0.4 \\
Eigenvalue & 6.7 & 1.2 & 4.6 \\
Variance \% & 74.9 & 13.4 & \\
\hline
\end{tabular}

\subsection{PCA of soil data on tills}

Principal component analysis was carried out using the logtransformed surface soil geochemical data from the 4187 samples. Results of the first three components, which account for $92.9 \%$ of the total variance, are listed in Table 2 . The amount of variability contained by each PC is expressed by the eigenvalues. Principal component 1 (PC1) accounts for $74.9 \%$ of the total variance and is dominated by elements $\mathrm{Al}-\mathrm{Fe}-\mathrm{Ga}-\mathrm{K}-\mathrm{La}-\mathrm{Mg}-\mathrm{Rb}$ with a slightly less strong Sr-Ca component (Table 2). Elements associated in PC1 can be linked with clay minerals and suggest a clay signature in a majority of the surface soils. PC2 accounts for a further $13.4 \%$ and is associated with a strong $\mathrm{Ca}-\mathrm{Sr}$ signature, which relate to highly calcareous soils within the used set of samples. Elements indicating clay-rich soils seen by PC1 are inversely related. The very dominant clay signal of PC1 is also illustrated by loading and score plots for PC1 and PC2 of Fig. 5.

Potassium is the most dominant factor in PC3 representing a further $4.6 \%$ of the total variance, with Fe showing a very strong inverse relationship to $\mathrm{K}$.

Additionally, principal component scores were calculated which express the magnitude of each component (e.g. PC1 to PC3) for each sample site. These are plotted in Fig. 6 to show the spatial distribution of the magnitude of each component relative to the 25th, 50th, 75th and 90th percentile classes.

The distribution of scores for PC1 ( -0.82 skewness) reflects the element association of $\mathrm{Al}, \mathrm{Fe}, \mathrm{Ga}, \mathrm{K}, \mathrm{La}, \mathrm{Mg}$ and $\mathrm{Rb}$ which accounts for over $50 \%$ of the sites. The spatial distribution of PC1 scores is very distinctive (Fig. 6). High scores plot across much of the East Midlands and the southern part of East Anglia, with the highest scores plotting to the southwest of Cambridge. Scores of zero or below typically plot across much of northern East Anglia and further west in the vicinity of Birmingham.

The score plot of PC2 characterises surface soils containing high levels of $\mathrm{Ca}$ and $\mathrm{Sr}$ (Fig. 6). The scores are positively skewed (1.36) and have a median value of -0.26 . The score plot shows
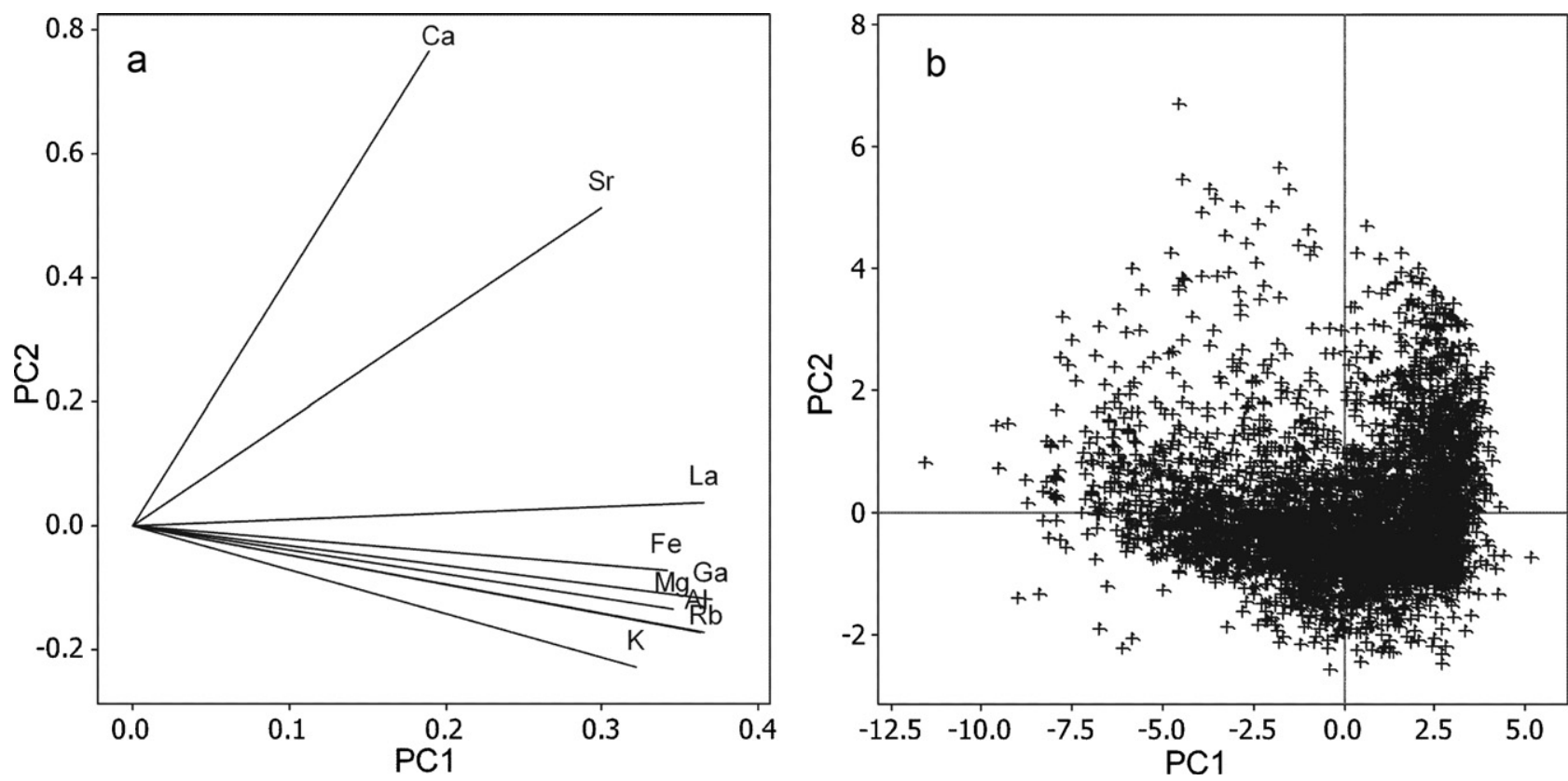

Fig. 5. PCA results of PC1 and PC2 displayed against each other as (a) loading and (b) score plots. 

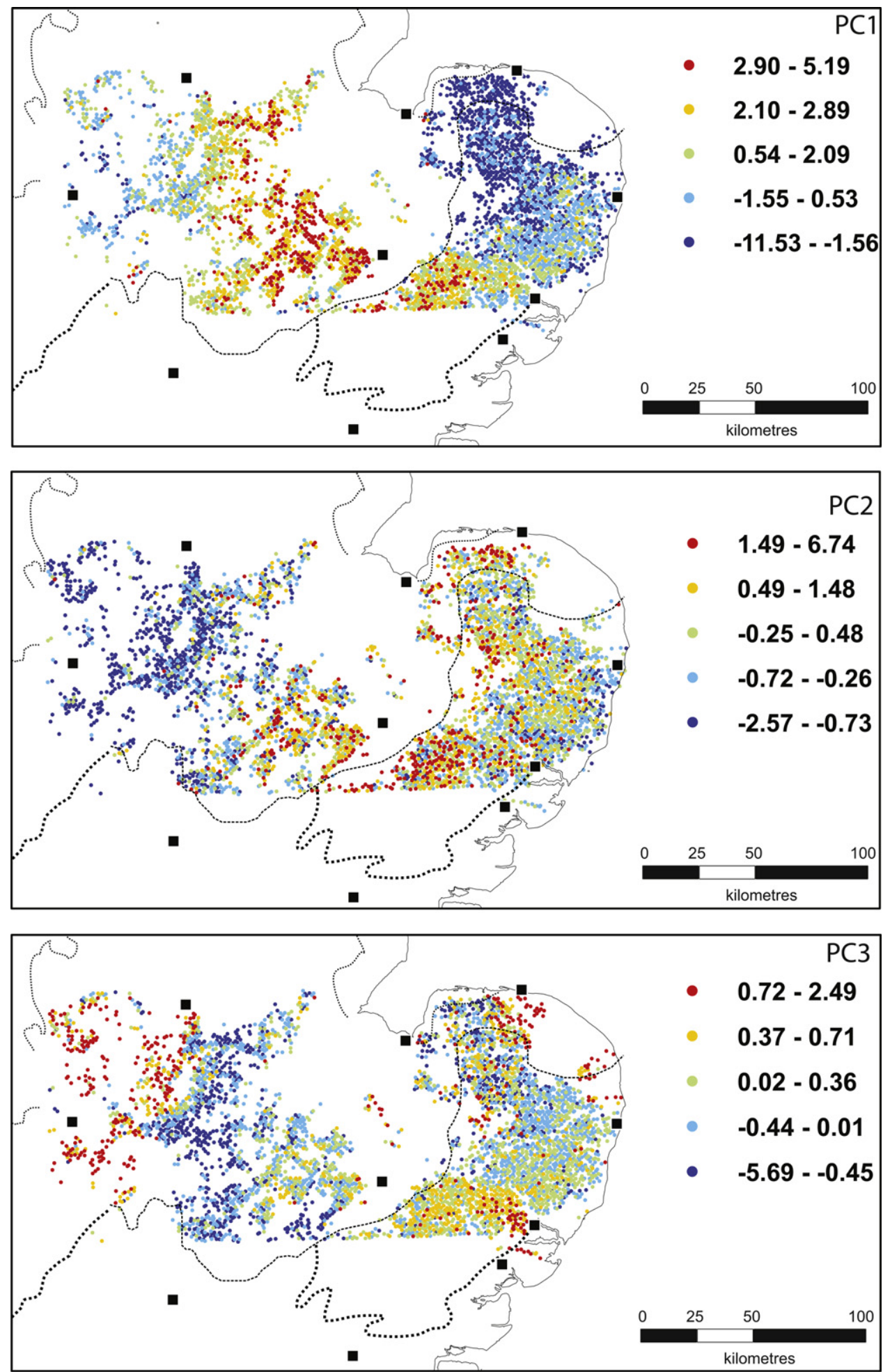

Fig. 6. Maps displaying principal component scores calculated for PC1, PC2 and PC3 for each sample site in relation to the extent of the 'lower' and 'upper' till sheets.

that high PC2 scores can be found throughout northern East Anglia especially in northwest Norfolk adjacent King's Lynn and in southern East Anglia and the South Midlands. Within central East Anglia, there is a general weakening of PC2 from west to east. Localised moderate to high PC2 scores occur in the East Midlands, whilst surface soils developed on tills to the south and west of Nottingham have zero or negative scores based on PC2.
The distribution of principal component scores accounted for by PC3 is shown in Fig. 6. The score represents strong $\mathrm{K}$ values and its inverse relationship to Fe and is characterised by a median score of 0.01 and a negative skewness $(-0.52)$. High PC3 scores occur within soils in the west of the study area between Birmingham and Nottingham, but decline sharply to the east of this line and scores over the East Midlands are generally zero or negative. In East Anglia, moderate to high scores are present within the south 


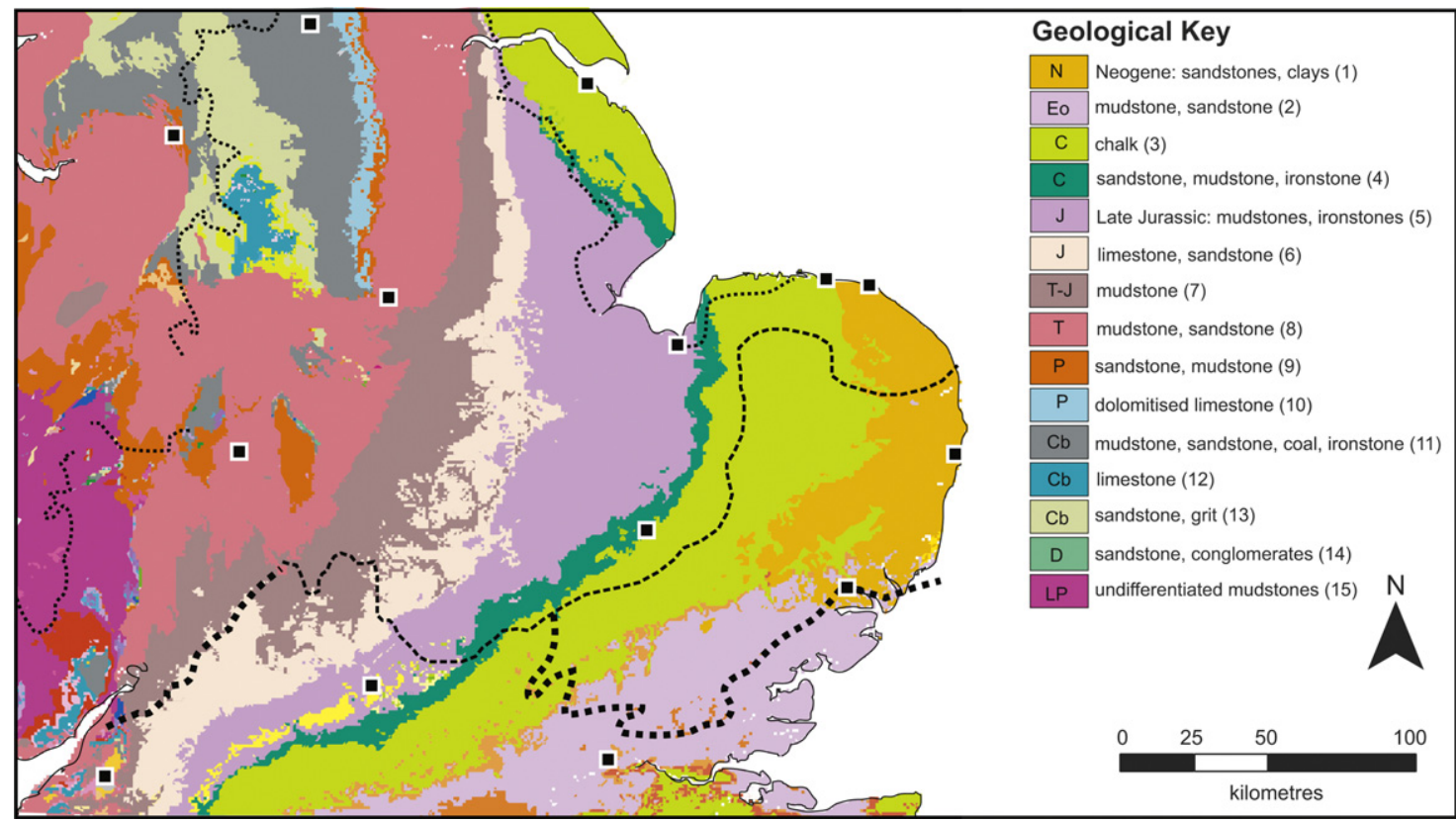

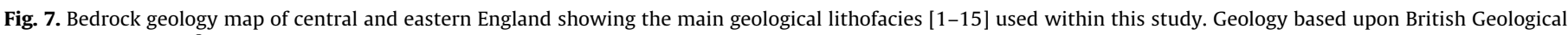
Survey Great Britain ${ }^{\odot}$ DiGMapGB, NERC (2010).

between Cambridge and Ipswich. High values are also present in soils within central northern East Anglia.

\section{Provenance of geochemical elements and till sheets}

\subsection{Provenance of geochemical elements}

Soil geochemical data from 4581 sites collected over bedrock outcrops were used to establish the levels of $\mathrm{Al}, \mathrm{Ca}, \mathrm{Fe}, \mathrm{Ga}, \mathrm{K}, \mathrm{La}, \mathrm{Mg}$, $\mathrm{Rb}$ and $\mathrm{Sr}$ within the principal bedrock units in central England and East Anglia. The geochemical composition of these bedrock units (Fig. 7) is shown within box plots in Fig. 8. Not surprisingly, most significant concentrations of Ca are those within soils developed on limestone or chalk bedrock. The median Ca value for surface soil developed on Cretaceous Chalk ([3] in Figs. 7 and 8) is $47,528 \mathrm{mg} /$ $\mathrm{kg}(4.8 \%)$, with lesser median values $(18,296 \mathrm{mg} / \mathrm{kg} ; 1.8 \%)$ for soils developed over Jurassic limestone. All remaining geological units indicate Ca levels in surface soils below 1\%. High levels of $\mathrm{Sr}$, associated with $\mathrm{Ca}$ due to substitution in carbonate minerals, are similar to Ca but not as distinct. Both $\mathrm{Ca}$ and $\mathrm{Sr}$ occur in elevated concentrations in the Chalk [3] and limestone and sandstone [6], with singular high $\mathrm{Sr}$ values in Cretaceous sandstone, mudstone and ironstone [4].

The main mineral forming elements ( $\mathrm{Al}, \mathrm{Ca}, \mathrm{Fe}, \mathrm{K}$ and $\mathrm{Mg}$ ) as well as elements $\mathrm{Ga}$, $\mathrm{La}$ and $\mathrm{Rb}$ are all elevated in mudstones and sandstones of Jurassic to Triassic age. Potassium and Mg are most dominant within Triassic mudstones and sandstone [8], and glauconitic Cretaceous sandstones, mudstone and ironstone [4]. Moderate values of $\mathrm{K}$ are also present within glauconite-rich Eocene and Neogene age sandstones and clays [1,2]. Elevated concentrations of $\mathrm{Al}, \mathrm{Fe}, \mathrm{Ga}$ and La are mainly associated with Jurassic sedimentary rocks [5-7] of which the Triassic-Jurassic mudstone [7] seems to be most dominant carrier. Rubidium is elevated in Cretaceous sandstones, mudstones and ironstones [4], Jurassic $[5,6]$ and Triassic $[7,8]$ bedrock, Permian sandstone and mudstone [9], Carboniferous mudstone, sandstone, coal and ironstone [11] strata as well as the Lower Palaeozoic mudstones [15]. Moderate to high concentrations of Fe occurs within many bedrock strata, especially the Cretaceous sandstone, mudstone and ironstone [4], Jurassic lithologies [5, 6], Triassic-Jurassic mudstones [7] and Permian mudstones and sandstones [9].

\subsection{Provenance of till sheets}

\subsubsection{The 'lower till sheet'}

Samples collected to the east and south of the limit of the Oadby Till and Sheringham Cliffs Formation limit in Fig. 1 are developed on tills that form part of the 'lower till sheet'. This group spans much of southern and central East Anglia and is dominated by the Lowestoft Till Member.

The LTM of central and southern East Anglia possesses a variable and complex geochemical signature but its geochemical signature is strongly influenced by locally derived bedrock lithologies. High PC1 scores, reflect the incorporation of Jurassic mudstones, ironstone and sandstone [5] from the west into the till within the south of the region. This signal is replaced north and eastwards by PC2 which reflects incorporation of Cretaceous Chalk [3] bedrock into the till across the whole of central and southern East Anglia. Moderate to high PC3 scores, indicate input of glauconite-rich bedrock into the Lowestoft Till Member in southern East Anglia. The low Fe content associated with PC3 implies that the Cretaceous sandstone, mudstone and ironstone [4] are unlikely to be the source. Instead, derivation from some of the Neogene or Eocene sandstones and mudstones [1,2] of eastern East Anglia appears to be more likely. The weakening trend of the PC3 signal northwards into East Anglia can be explained by the burial of Neogene lithologies by Quaternary sediments and their incorporation into the till.

\subsubsection{The 'upper till sheet'}

The 'upper till sheet' encompasses sample points to the north and east of the OTM and Sheringham Cliffs Formation limit in Fig. 1. The OTM of central England and the Fen Basin contains a variable geochemical composition that shows a range of trends within PC1 to PC3 broadly aligned west-east. The strength of PC1 within the south and east of central England reflects high incorporation of Late Jurassic mudstone and ironstone [5] and Jurassic limestone and sandstone [6] and Triassic-Jurassic mudstone [7], which 

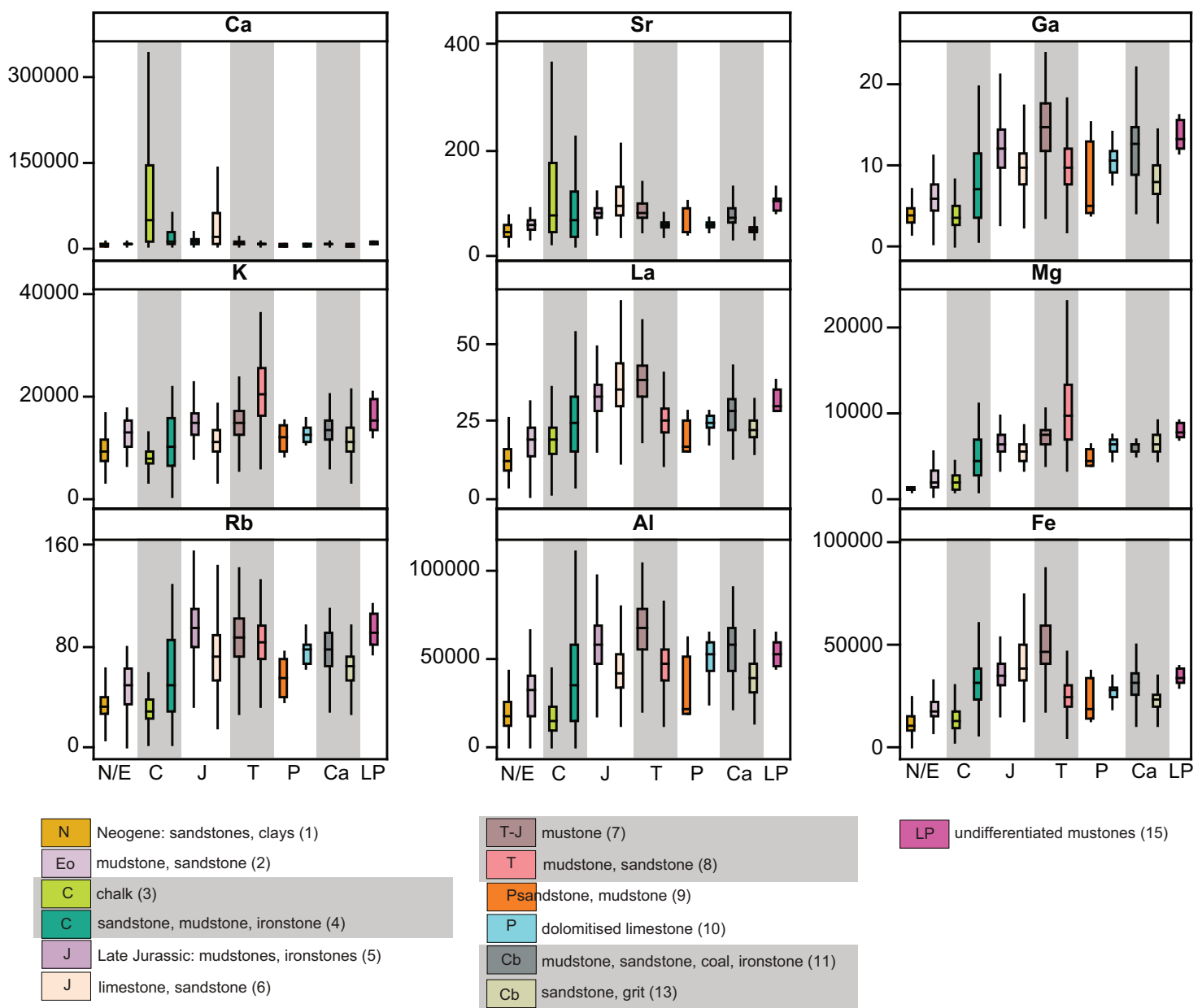

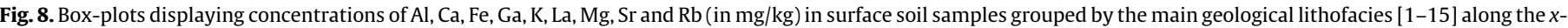

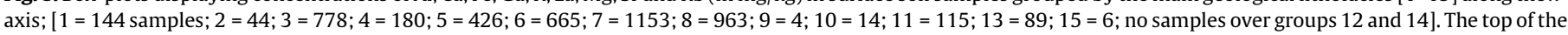

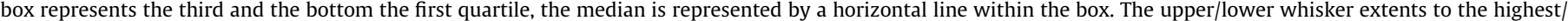
lowest data value within the upper/lower limits [upper limit = Q3 + 1.5(Q3 - Q1); lower limit = Q1 - 1.5(Q3 - Q1)].

decreases eastwards. Elevated PC2 values derived principally from the Chalk [3] occur within the OTM in the South Midlands to the west of the Chalk outcrop and decrease broadly westwards. The PC3 signal is complex. Moderate PC3 values, reflecting a $\mathrm{K}-\mathrm{Fe}$ signal to the west of Cambridge, are diagnostic of input of Cretaceous sandstone, mudstone and ironstone [4] situated to the east. To the east of Nottingham, strong negative PC 3 values suggest that the Fe content of the OTM has increased relative to K. The source of this geochemical signal could be locally incorporated Jurassic limestone and sandstone [6] and Triassic-Jurassic mudstone [7]. South and west of Nottingham, the OTM possesses very high PC3 values reflecting a strong K/low Fe signal characteristic of local incorporation of Triassic mudstone and sandstone [8].

In northern East Anglia, the WTTM of the Sheringham Cliffs Formation possesses a distinctive geochemical signature. Low PC1 values suggest that the till does not contain material derived from the Triassic to Jurassic sediments to the west [5-7]. Instead, high PC2 values demonstrate the WTTM is dominated by the incorporation of locally derived Chalk [3]. PC3 values show two distinct trends. To the east of the Glaven Valley, the WTTM shows high PC3 values reflecting a high $\mathrm{K}$ to Fe ratio. The precise source of this signal is unclear although the high $\mathrm{K}$ content is diagnostic of argillaceous sediments (e.g. muds or mudstones) that maybe derived from preexisting Quaternary, older Neogene [1] and/or Eocene [2] sediments derived from north Norfolk or the now offshore area to the north. To the west of the Glaven Valley, the WTM exhibits a more variable but lower PC3 signal reflecting higher and variable levels of Fe within the till. This could either reflect localised oxidation of the WTTM or variable incorporation of the Cretaceous sandstone (Carstone), mudstone and ironstone [4] which lie to the west. Low PC3 values reflecting high Fe content, could equate to the entrainment of locally oxidised beds of Carstone.

\section{Discussion}

\subsection{Geochemical signals and ice-substrate interactions}

One of the most striking features of the dataset is that the bulk composition of both the 'upper' and 'lower' till units are dominated by a locally inherited bedrock geochemical signature. This observation is similar to results obtained from other lithological proxies examined within the tills such as clast and matrix lithologies (e.g. Straw, 1983; Allen et al., 1991; Lee et al., 2004). Spatial plots of the derived geochemical data also reveal that both till sheets inherit a new bedrock-derived geochemical signature within a small spatial distance - typically within ca. $15 \mathrm{~km}$, of ice crossing a major bedrock boundary. This 'smudging' demonstrates that the British Ice Sheet, which deposited both till sheets, was actively eroding and entraining subglacial materials from successive bedrock units along most of its flow trajectory. However, the relative strength of the spatial geochemical trends within the dataset was unexpected. Kjær et al. (2003), for example, argued 
that the far-travelled lithological component of tills increases with height within a till profile - a function of reduced interaction of basal ice with local lithologies as substrate is progressively buried by till. Whilst we are not presenting vertical profile data within this study, the degraded and undulating surface of both till sheets should, following this theory, leave a more spatially variable and weaker geochemical trend reflecting different levels of outcropping till. This pattern is not shown by the dataset. Instead, we argue that the relatively strong and clean geochemical signal reflects multiple episodes of recycling, deposition and homogenisation (cf. Larsen et al., 2004; Boston et al., 2010).

A further feature of the geochemical data-set is that no major discernable changes in till geochemistry are evident adjacent to the line delineating the 'upper' and 'lower' till sheets. This highlights and reinforces the observations made previously that the bulk lithologies of many of the tills in the study area are overwhelming locally derived in nature, and that tills can inherit new lithological characteristics within km's of crossing a major lithological change in substrate. An obvious example of this is the chalky LTM and WTTM of western and southern Norfolk - the former derived from the west, the latter from the north, but both containing a similar geochemical signal inherited from the Cretaceous Chalk and Jurassic mudstones.

\subsection{Geochemistry-based ice flow model}

Analysis of soils developed on Middle Pleistocene till in central England and East Anglia shows that their geochemical signature is inherited from these till sheets. In-turn, the geochemical composition of the till sheets is shown to be derived from the assimilation of different bedrock lithologies that have been eroded and incorporated into the subglacial bed. Whilst much of the geochemical character of these till sheets is derived locally, as stated previously, the direction of 'smudging' provides a useful directional indicator of ice flow. A 'broad-brush' ice flow model, based purely upon the geochemical composition of the two till sheets is presented below although it should be noted that no attempt has been made to extend the model beyond the spatial limits of the geochemical signatures (Fig. 9).

\subsection{1. 'Lower till sheet'}

The inherited geochemical signature of the LTM, forming part of the 'lower till sheet' in central and southern East Anglia, is largely derived from the localised incorporation of Jurassic and Cretaceous Chalk lithologies. The strongest geochemical signal is however derived from the Jurassic mudstones, ironstones and limestones situated to the west in the East and South Midlands.

An intriguing geochemical feature of the dataset is the zero to negative PC1 scores to the north of Thetford within west Norfolk. It implies that the till does not contain a geochemical signature derived from Jurassic lithologies within the Fen Basin or further west, but that it is largely inherited from the underlying Chalk bedrock. In many respects this discovery is consistent with the earlier thoughts of West and Donner (1956) and Cox and Nickless (1972) who considered that highly chalky facies of till in this area were derived from ice flowing broadly southwards down the strike of the Chalk. However, detailed examination of the microfossil content of the highly chalky facies, does demonstrate the presence of westerly derived Triassic [8] and Late Jurassic [5] lithologies within the LTM (Riding, 2008). Three possible explanations exist: (1) the Chalk geochemical signal (PC2) has masked the Jurassic content of the till (PC1); (2) smaller amount of erosion and entrainment of Jurassic material occurred within the northern part of the present Fen Basin than the southern part; (3) much higher rates of Chalk erosion and entrainment occurred within the northern part of the present Fen Basin than the southern part. Upon

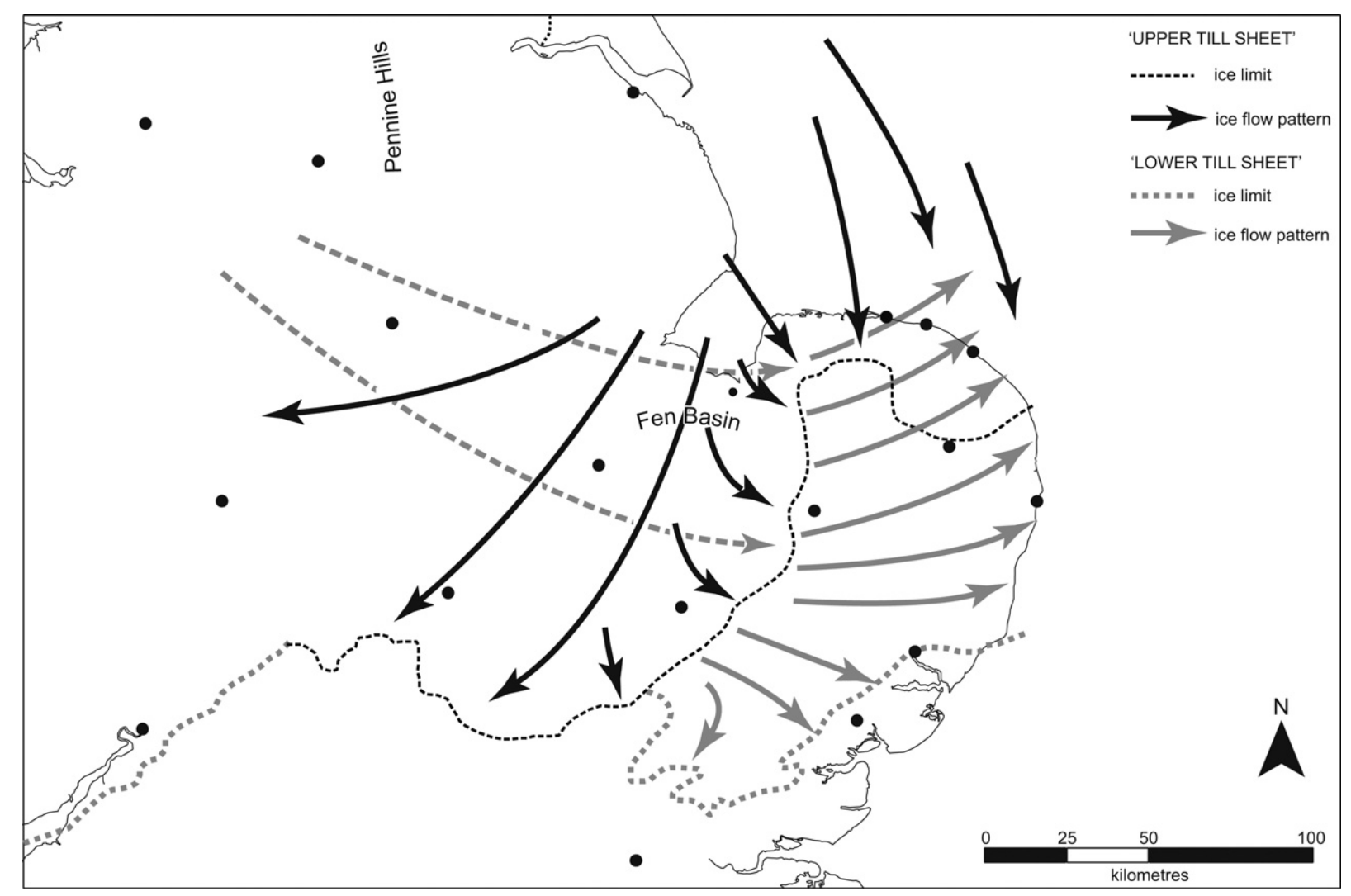

Fig. 9. Schematic cartoons showing the broad-brush reconstructed ice flow map for the lower and upper till sheets based upon the soil geochemistry data. 
evaluating each of these explanations in-turn, it seems probable that much higher rates of Chalk erosion and entrainment (relative to Jurassic material) was the dominant factor in controlling the zero to negative PC1 scores within the LTM. This view is supported by the much lower relief of the Chalk escarpment adjacent to the northern rather than southern part of the Fen Basin, and attributed by Clayton (2000) to glacial erosion during the Middle Pleistocene.

The geochemical composition of the LTM within the study area demonstrates that the till was derived from ice flowing broadly west to east across the region (Fig. 9). However, geochemical data is unable to extend the ice flow path westwards beyond the western-most Jurassic outcrop. Other lithological data from the till including Carboniferous and Triassic palynomorphs (Lee, 2003; Riding, 2008) and Carboniferous erratics (Lewis et al., 1999; Lee et al., 2004) enable the till flow path to be extended westwards indicating a Pennine ice source. In north Norfolk, the northern extent of this ice advance from the west is characterised by an extensive glaciotectonic overprint, that has deformed part of the underlying glacigenic sediment pile, and deposited a lower-level westerly derived chalky till (Banham and Ranson, 1965; Ehlers et al., 1987; Lee and Phillips, 2008; Phillips et al., 2008).

\subsection{2. 'Upper till sheet'}

The flow history from northern East Anglia is complex (Fig. 9). To the east of the Glaven Valley, an inverse relationship between PC1 and PC2 characterise the highly chalky till of the WTTM with minimal Jurassic input. Elevated PC3 concentrations are speculated to be derived from argillaceous lithologies eroded either in present offshore areas to the north, or from pre-existing Quaternary deposits (e.g. 'Crag' or glaciolacustrine deposits) in north Norfolk. Together, the principal component scores imply that eastern occurrences of WTTM were laid-down by ice flowing broadly north to south into north Norfolk. By contrast, to the west of the Glaven Valley the WTTM exhibits a more variable geochemistry especially in scores PC2 and PC3. The low PC3 signal of the WTTM in northwest Norfolk characterises a high $\mathrm{Fe}$ content suggesting derivation from ice eroding Greensand/Carstone [4] outcrops along the Cretaceous escarpment situated to the west. The moderate to high PC2 scores point to the fact that moderate to high quantities of locally derived. Furthermore, the PC1 scores are low in this region indicating minimal input of Jurassic mudstone from the west [5]. This implies that ice in northwest Norfolk was deposited by ice flowing over and eroding mainly Cretaceous rocks to the north and northwest (Fig. 9). Alternatively, some of the points may correspond to elements of the 'lower till sheet' that have been glaciotectonically disturbed. Across central England and the Fen Basin, the distribution of PC1 and PC2 within the OTM is consistent with the flow of ice broadly from northeast to southwest and west across the region (Fig. 9). This is supported by the westwards 'smudge' of geochemical characteristics derived from Cretaceous [3, 4], Jurassic [5, 6], Triassic-Jurassic [7] and lithologies.

In summary, geochemical data from the OTM and Sheringham Cliffs Formation characterise the incursion of North Sea ice into East Anglia and central England (Fig. 9). Within this model, North Sea ice appears to have flowed broadly southwards through eastern Lincolnshire and the present area of the North Sea. The eastern part of the North Sea ice flowed southwards into north and west Norfolk, whilst the western part breached the Chalk escarpment in The Wash, and extended south and westwards towards the South and West Midlands.

\subsection{Comparison with other ice flow models}

The model presented within Section 6.2 and Fig. 9 identifies two distinctive ice flow paths relating to the 'lower till sheet' attributed to a west-to-east flow of Pennine ice, and a later North
Sea advance towards the south and west associated with the 'upper till sheet'. This is in broad-level accordance with the models of West and Donner (1956) and Rose (1992) - especially in the flow path reconstructed for the 'lower till sheet'. Notable differences are evident in relation to the flow path of the 'upper till sheet'. Most obviously, the redefined limit of the 'upper till sheet' restricts the later incursion of North Sea ice into central England and East Anglia to the western side of the Chalk escarpment within the south of the region. This is supported by the existence of just LTM at a number of important Cromerian and Hoxnian archaeological sites in western central East Anglia which implies that the later ice advance associated with the 'upper till sheet' did not extend as far east (e.g. Rose, 1992; Preece et al., 2007; Ashton et al., 2008). Additionally, geochemical data from the WTTM in northwest Norfolk demonstrate a strong northwest/westerly derived ice flow component across the Wash similar to that suggested by Straw (1983) and later by Fish and Whiteman (2001). This implies a southwards flow of ice through eastern Lincolnshire not recognised by Perrin et al. (1979) or Rose (1992). Across central England, the ice flow path associated with the OTM is similar to that invoked by Rice (1968), Perrin et al. (1979), Shotton (1983) and Rose (1992).

Several models, most notably Perrin et al. (1979), Rose (1992) and Fish and Whiteman (2001), also comment on the significance of the Scandinavian Ice Sheet situated adjacent-to and within north Norfolk. Fish and Whiteman (2001) for example, argue that British North Sea ice was partly constrained by Scandinavian ice forcing it southwards across central England and East Anglia. However, Lee et al. $(2002,2004)$ have recently concluded that tills in north Norfolk, previously considered to be of Scandinavian origin, are actually of British provenance. The westwards extent of the Scandinavian Ice Sheet within the North Sea during the Middle Pleistocene is therefore unclear and its level of interaction with British North Sea ice is ambiguous (Lee et al., in press). One possible explanation is that British ice extended into the North Sea from northern and eastern Britain as a large piedmont lobe (cf. Lee et al., 2002). This lobe of ice spread east, north and southwards into the North Sea under its own weight on soft deformable sediments. In such a scenario, the incursion of ice through the Wash would be generated by the mass of the British Ice Sheet itself without the need for coalescence with Scandinavian ice. Clearly, this explanation is speculative and a greater understanding of the provenance of Middle Pleistocene tills within the North Sea Basin is required to fully understand the context of the North Sea sector of the British Ice Sheet during this glaciation.

Comparison of the ice flow model presented here with others that have been published elsewhere also highlights several wider issues. Various techniques have been employed on the tills to determine ice flow directions including structural analysis (West and Donner, 1956; Allen et al., 1991), clast lithologies (Kelly and Rawson, 1983; Straw, 1983; Allen et al., 1991; Lee et al., 2004), micropalaeontology (Fish et al., 2000; Fish and Whiteman, 2001; Riding, 2001, 2004, 2008), heavy minerals (Perrin et al., 1979; Lee et al., 2004) and all have produced valuable data. The fundamental differences between the various models are however, largely related to the stratigraphy employed within each model. It highlights the importance of understanding the regional-scale three-dimensional geometry of major till sheets in reconstructing the dynamics of Pleistocene ice sheets.

\section{Conclusions}

- High resolution geochemical data provides a proxy with which the flow paths of former ice sheets can be delineated.

- Geochemical analysis of soils in central England and East Anglia reveal that much of their geochemical character is inherited from the tills that they are developed upon. 
- The geochemical signature of different till units is largely derived from local bedrock sources with dilution and a new geochemical signature acquired as the ice flows over and incorporates new bedrock lithologies.

- Three statistically significant associations of geochemical elements are demonstrated by principal component analysis that account for almost $93 \%$ of the geochemical variance. The latter represent clay and calcareous signatures in soils that indicate several bedrock units with strong and distinctive geochemical fingerprints.

- Provenancing of these geochemical elements enables ice flow paths associated with two different Middle Pleistocene 'chalky' till sheets to be constructed. Firstly, a lower till sheet composed of Lowestoft Formation till, relating to 'Pennine' ice flowing from west to east across the region, and a minor component of 'North Sea' ice extending into northeast Norfolk. Secondly, an upper till sheet comprising the Weybourne Town Till and Oadby Till members, deposited by North Sea Ice moving into northern East Anglia, and to the west of the Fen Basin, before fanning-out across central England.

- Elements of the Weybourne Town Till Member possess a 'northwestern' or 'western' geochemical signature, suggesting ice flowing east to southeastwards across The Wash.

\section{Acknowledgements}

The authors acknowledge the efforts of all student samplers and BGS staff involved in G-BASE sampling campaigns, sample preparation, analysis and data processing. We also wish to thank a number of individuals for their friendly and constructive discussions over the years regarding the provenance of the "chalky till' - most notably Richard Hamblin, Brian Moorlock, Jim Rose and Colin Whiteman. Clare Boston and Steve Booth are thanked for their constructive thoughts and comments on an earlier version of the manuscript, whilst the views of two referees are gratefully acknowledged. We publish with the permission of the Executive Director of the British Geological Survey (NERC).

\section{References}

Allen, P., Cheshire, D.A., Whiteman, C.A., 1991. The tills of southern East Anglia. In: Ehlers, J., Gibbard, P.L., Rose, J. (Eds.), Glacial Deposits in Great Britain and Ireland. Balkema, Rotterdam, pp. 255-278.

Ashton, N., Lewis, S.G., Parfitt, S.A., Penkman, K.E.H., Coope, G.R., 2008. New evidence for complex climate change in MIS 11 from Hoxne, Suffolk, UK. Quaternary Science Reviews 27, 652-688.

Baden-Powell, D.F.W., 1948. The chalky boulder clays of Norfolk and Suffolk. Geological Magazine 85, 279-296.

Banham, P.H., Ranson, C.E., 1965. Structural study of the contorted drift and disturbed chalk at Weybourne, North Norfolk. Geological Magazine 102, $164-173$.

Barron, A.J.M., Morigi, A.N., Reeves, H.J., 2006. Geology of the Wellingborough District - a brief explanation of the geological map. Sheet Explanation of the British Geological Survey. 1:50 000 Sheet 186. Wellingborough (England and Wales) British Geological Survey, Keyworth, Nottingham, 34 pp.

Benn, D.I., Evans, D.J.A., 1998. Glaciers and Glaciation. Edward Arnold, London, 734 pp.

Boston, C.M., Evans, D.J.A., Ó Cofaigh, C., 2010. Styles of till deposition at the margin of the Last Glacial Maximum North Sea lobe of the British-Irish Ice Sheet: an assessment based on geochemical properties of glacigenic deposits in eastern England. Quaternary Science Reviews 29, 3184-3211.

Bowen, D.Q. (Ed.), 1999. A revised correlation of Quaternary deposits in the British Isles. Special Report No. 23, Geological Society of London.

Bradwell, T., Stoker, M.S., Golledge, N.R., Wilson, C., Merritt, J., Long, D., Everest, J.D., Hestvik, O., Stevenson, A., Hubbard, A., Finlayson, A., Mathers, H., 2008. The northern sector of the last British ice sheet: maximum extent and demise. Earth Science Reviews 88, 207-226.

Carney, J.N., Ambrose, K., 2007. Geology of the Leicester district - a brief explanation of the geological map. Sheet Explanation of the British Geological Survey. 1:50 000 Sheet 156, Leicester (England and Wales) British Geological Survey, Keyworth, Nottingham, $34 \mathrm{pp}$.

Catt, J.A., 1979. Soils and Quaternary Geology in Britain. Journal of Soil Science 30, 607-642.
Cheng, Q., Jing, L., Panahi, A., 2006. Principal component analysis with optimum order sample correlation coefficient for image enhancement. International Journal of Remote Sensing 27 (16), 3387-3401.

Clark, C.D., Evans, D.J., Khatwa, A., Bradwell, T., Jordan, C.J., Marsh, S.H., Mitchell, W.A., Bateman, M.D., 2003. Map and GIS database of glacial landforms and features related to the last British Ice Sheet. Boreas 33, 359-375.

Clark, C.D., Gibbard, P.L., Rose, J., 2004. Pleistocene glacial limits in England, Scotland and Wales. In: Ehlers, J., Gibbard, P.L. (Eds.), Quaternary Glaciations Extent and Chronology. Part I. Europe. Elsevier Publishers, Amsterdam, pp. 47 82.

Clark, C.D., Hughes, A.L.C., Greenwood, S.L., Jordan, C., Sejrup, H.P., 2010. Pattern and timing of retreat of the last British-Irish Ice Sheet. Quaternary Science Reviews, in press, doi:10.016/j.quatscirev.2010.07.019.

Clark, P.U., 1987. Subglacial sediment dispersal and till composition. Journal of Geology 95, 527-541.

Clayton, K.M., 2000. Glacial erosion of the Wash and Fen Basins and deposition of the chalky till of eastern England. Quaternary Science Reviews 19, 811-822.

Cox, F.C., Nickless, E.F.P., 1972. Some aspects of the glacial history of Norfolk Bulletin of the Geological Survey of Great Britain 42, 79-98.

Davies, B.J., Bridgland, D.H., Roberts, D.H., Ó Cofaigh, C., Pawley, S.M., Demarchi, B. Penkman, K.E.H., Auston, W., 2009. The age and stratigraphic context of the Easington raised beach, County Durham, UK. Proceedings of the Geologists' Association 120, 183-198.

Ehlers, J., Gibbard, P.L., Whiteman, C.A., 1987. Recent investigations of the Marly Drift of northwest Norfolk, England. In: van der Meer, J.J.M. (Ed.), Tills and Glaciotectonics. Balkema, Rotterdam, pp. 39-54.

Evans, H., 1975. The two till problem in west Norfolk. Bulletin of the Geological Society of Norfolk 27, 61-75.

Fish, P.R., Whiteman, C.A., Moorlock, B.S.P., Hamblin, R.J.O., Wilkinson, I.P., 2000. The glacial geology of the Weybourne area: a new approach. Bulletin of the Geological Society of Norfolk 50, 21-45.

Fish, P.R., Whiteman, C.A., 2001. Chalk micropalaeontology and the provenancing of Middle Pleistocene Lowestoft Formation Till in eastern England. Earth Surface Processes and Landforms 26, 953-970.

Gallois, R.W., 1994. Geology of the country around King's Lynn and The Wash. Memoir of the Geological Survey, sheet 145 and part of 129 (England and Wales) HMSO, London.

Gibbard, P.L., 1986. Comparison of the clast lithological composition of gravels in the Middle Thames using canonical variates analysis and principal components analysis. In: Bridgland, D.R. (Ed.), Clast Lithological Analysis. Technical Guide No. 3, Quaternary Research Association, Cambridge.

Greenwood, S.L., Clark, C.D., 2008. Subglacial bedforms of the Irish Sheet. Journal of Maps 2008, 332-357.

Grunsky, E., Smee, B.W., 1999. The differentiation of soil types and mineralization from multi-element geochemistry using multivariate methods and digital topography. Journal of Geochemical Exploration 67, 287-299.

Hamblin, R.J.O., Moorlock, B.S.P., Rose, J., Lee, J.R., Riding, J.B., Booth, S.J., Pawley, S.M., 2005. Revised Pre-Devensian glacial stratigraphy in Norfolk, England based on mapping and till provenance. Geologie en Mijnbouw 84, 77-85.

Hart, J.K., 2007. An investigation of subglacial shear zone processes from Weybourne, Norfolk, UK. Quaternary Science Reviews 26, 2354-2374.

Hart, J.K., Hindmarsh, R.C.A., Boulton, G.S., 1990. Styles of subglacial glaciotectonic deformation within the context of the Anglian ice-sheet. Earth Surface Processes and Landforms 15, 227-241.

Hopson, P.M., Bridge, D.McC., 1987. Middle Pleistocene stratigraphy in the lower Waveney valley, East Anglia. Proceedings of the Geologists' Association 98, 171-185.

Ingham, M.N., Vrebos, B.A.R., 1994. High productive geochemical XRF analysis. In: Gilfrich, J.V., et al. (Eds.), Advances in X-ray Analysis, vol. 37. Springer, New York, pp. 717-724.

Johnson, C.C., Breward, N., Ander, E.L., Ault, L., 2005. G-BASE: baseline geochemica mapping of Great Britain and Northern Ireland. Geochemistry: Exploration, Environment, Analysis 5 (4), 347-357.

Johnson, C.C., Ander, E.L., Lister, T.R., Flight, D.M.A., 2008. Data conditioning of environmental geochemical data: Quality control procedures used in the British Geological Survey's regional geochemical mapping project. In: De Vivo, B., Belkin, H.E., Lima, A. (Eds.), Environmental Geochemistry: Site Characterization, Data Analysis and Case Histories. (Chapter 5), pp. 93117.

Kalm, V. Ice flow pattern and extent of the last Scandinavian Ice Sheet southeast of the Baltic Sea. Quaternary Science Reviews, in press, doi:10.1016/j.j. quatscirev.2010.01.019.

Kelly, S.R.A., Rawson, P.F., 1983. The distribution of Spilsby Sandstone erratics. Proceedings of the Geologists' Association 94, 65-73.

Kjær, K.H., Houmark-Nielsen, M., Richardt, N., 2003. Ice-flow patterns and dispersal of erratics at the southwestern margin of the last Scandinavian Ice Sheet: signature of palaeo-ice streams. Boreas 32, 130-148.

Klassen, R.A., 2001. The interpretation of background variation in regional geochemical surveys - an example from Nunavut, Canada. Geochemistry: Exploration, Environment, Analysis 1 (2), 163-173.

Kovach, W.L., 1995. Multivariate data analysis. In: Maddy, D., Brew, J.S. (Eds.), Statistical modelling of Quaternary Science Data. Technical Guide No. 5. Quaternary Research Association, Cambridge, pp. 1-38.

Larsen, N.K., Piotrowkski, J.A., Kronborg, C., 2004. A multiproxy study of a basal till: a time-transgressive accretion and deformation hypothesis. Journal of Quaternary Science $19,9-21$. 
Larson, P., Mooers, H., 2005. Generation of heavy-mineral glacial indicator dispersal train from a diabase sill, Nipigon region, northwestern Ontario. Canadian Journal of Earth Sciences 42 (9), 1601-1613.

Lee, J.R., 2003. Early and Middle Pleistocene lithostratigraphy and palaeoenvironments in northern East Anglia, UK. Unpublished PhD Thesis, Royal Holloway University of London.

Lee, J.R., Rose, J., Riding, J.B., Moorlock, B.S.P., Hamblin, R.J.O., 2002. Testing the case for a Scandinavian glaciation in Eastern England: evidence for a Scottish ice source for tills within the Corton Formation of East Anglia, UK. Boreas 31, 345-355.

Lee, J.R., Booth, S.J., Hamblin, R.J.O., Jarrow, A.M., Kessler, H., Moorlock, B.S.P., Morigi, A.N., Palmer, A., Pawley, S.J., Riding, J.B., Rose, J., 2004. A new stratigraphy for the glacial deposits around Lowestoft, Great Yarmouth, North Walsham and Cromer, East Anglia, UK. Bulletin of the Geological Society of Norfolk 53, 3-60.

Lee, J.R., Phillips, E., 2008. Progressive soft sediment deformation within a subglacial shear zone - a hybrid mosaic-pervasive deformation model for Middle Pleistocene glaciotectonised sediments from Eastern England. Quaternary Science Reviews 27, 1350-1362.

Lee, J.R., Busschers, F., Sejrup, H.P. Pre-Weichselian Quaternary glaciations of the British Isles, The Netherlands, Norway and adjacent marine areas south of $68^{\circ} \mathrm{N}$ : implications for long-term ice sheet development in northern Europe. Quaternary Science Reviews, in press, doi:10.1016/j.quatscirev.2010.02.027.

Lehoten, M.L., Marmo, J.S., Nissinen, A.J., Johanson, B.S., Pakkanen, L.K., 2005. Glacial dispersal studies using indicator minerals and till geochemistry around two eastern Finland kimberlites. Journal of Geochemical Exploration 87, 19-43.

Lewis, S.G., Rose, J., Davies, H., 1999. Pre-Anglian fluvial and Anglian glaciogenic sediments, Knettishall, Suffolk, England. Proceedings of the Geologists' Association 109, 17-32.

Mathers, S.J., Zalasiewicz, J.A., Bloodworth, A.J., Morton, A.C., 1987. The Banham Beds: a petrologically distinct suite of Anglian glacigenic deposits from centra East Anglia. Proceedings of the Geologists' Association 98, 229-240.

McClenaghan, M.B., Lavin, O.P., Nichol, I., Shaw, J., 1992. Geochemistry and clast lithology as an aid to till classification, Matheson, Ontario, Canada. Journal of Geochemical Exploration 42 (2), 237-260.

Moorlock, B.S.P., Hamblin, R.J.O., Booth, S.J., Morigi, A.N., 2000. Geology of the Country around Lowestoft and Saxmundham. Memoir of the British Geological Survey, Sheets 176 and 191 (England and Wales) British Geological Survey, Nottingham.

Pawley, S.M., Rose, J., Lee, J.R., Hamblin, R.J.O., Moorlock, B.S.P., 2004. Middle Pleistocene stratigraphy of Weybourne, north-east Norfolk, England. Proceedings of the Geologists' Association 115, 22-42.

Pawley, S.M., Candy, I., Booth, S.J., 2006. The Devensian end-moraine complex at Garret Hill, Stiffkey valley, north Norfolk. Proceedings of the Yorkshire Geological Society 223, 33-41.

Perrin, R.M.S., Rose, J., Davies, H., 1979. The distribution, variation and origins of pre-Devensian tills in eastern England. Philosophical Transactions of the Royal Society of London B287, 535-570.

Phillips, E., Lee, J.R., Burke, H.K., 2008. Progressive proglacial to subglacial deformation and syntectonic deformation at the margins of the Mid-Pleistocene British Ice Sheet: evidence from north Norfolk, UK. Quaternary Science Reviews 27, 1848-1871.

Pointon, K.W., 1978. The Pleistocene succession at Corton, Suffolk. Bulletin of the Geological Society of Norfolk 30, 55-76.

Preece, R.C., Parfitt, S.A., Bridgland, D.R., Lewis, S.G., Rowe, P.J., Atkinson, T.C., Candy, I., Debenham, N.C., Penkman, K.E.H., Rhodes, E.J., Schwenniger, J.-L., Whittaker,
J.E., Gleed-Owen, C., 2007. Terrestrial environments during MIS 11: evidence from the Palaeolithic site at West Stow, Suffolk, UK. Quaternary Science Reviews $26,1236-1300$

Preece, R.C., Parfitt, S.A., Coope, G.R., Penkman, K.E.H., Ponel, P., Whittaker, J.E., 2009. Biostratigraphic and aminostratigraphic constraints on the age of the Middle Pleistocene glacial succession in north Norfolk, UK. Journal of Quaternary Science 24, 557-580.

Reimann, C., Filzmoser, P., 2000. Normal and lognormal data distribution in geochemistry: death of a myth. Consequences for the statistical treatment of geochemical and environmental data. Environmental Geology 39, 1001-1014.

Reimann, C., Filzmoser, P., Garrett, R.G., Dutter, R., 2008. Statistical Data Analysis Explained. John Wiley \& Sons Ltd., Chichester, UK.

Rice, R.J., 1968. The Quaternary deposits of central Leicestershire. Philosophical Transactions of the Royal Society of London A262, 459-509.

Richards, A.E., 1998. Re-evaluation of the Middle Pleistocene stratigraphy, Herefordshire, England. Journal of Quaternary Science 13, 115-136.

Richards, A.E., 2002. A multi-technique study of the glacial stratigraphy of Co. Clare and Co. Kerry, southwest Ireland. Journal of Quaternary Science 17, 261-276.

Riding. J.B., 2001. A palynological investigation of till samples from the Sheringham area, north Norfolk. British Geological Survey, Keyworth, Nottingham, Internal Report, IR/01/155, 17 pp.

Riding, J.B., 2004. A palynological investigation of two till samples from Leicestershire. British Geological Survey Internal Report, IR/04/173, 9 pp.

Riding, J.B., 2008. A palynological investigation of the Quaternary succession around Thetford, Norfolk, UK. British Geological Survey, Keyworth, Nottingham, Internal Report, IR/08/006, 12 pp.

Rose, J., 1989. Tracing the Baginton-Lillington Sands and Gravels from the West Midlands to East Anglia. In: Keen, D.H. (Ed.), Quaternary Research Association Field Meeting Guide - West Midlands. QRA, Cambridge, pp. 102-110.

Rose, J., 1992. High lodge - regional context and geological background. In: Ashton, N.M., Cook, J., Lewis, S.G., Rose, J. (Eds.), High Lodge: Excavations by G. de G. Sieveking, 1962-8 and J. Cook, 1988. British Museum Press, London, pp. 13-24.

Rose, J., 2009. Early and Middle Pleistocene landscapes of eastern England. Proceedings of the Geologists' Association 120, 3-33.

Sarala, P., 2005. Till geochemistry in the ribbed moraine area of Peräpohjola, Finland. Applied Geochemistry 20, 1714-1736.

Scheib, A.J., Breward, N., Lee, J.R., Lister, T.R., 2009a. A preliminary geochemical investigation of glacigenic till deposits in England using principal component analysis of G-BASE soil data. British Geological Survey, Keyworth, Nottingham, Internal Report, IR/08/027.

Scheib, A.J., Lee, J.R., Breward, N., Lister, T.R., 2009b. Regional geochemical soil data as aid to the reconstruction of Middle Pleistocene ice flows across central and eastern England. In: Proceedings of the 24th International Applied Geochemistry Symposium, vol. 2. pp. 569-572.

Scheib, A.J., Lee, J.R., 2010. The application of regional-scale geochemical data in defining the extent of aeolian sediments: The Late Pleistocene loess and coversand deposits of East Anglia, UK. Quaternary Newsletter 120, 5-14.

Shotton, F.W., 1983. The Wolstonian Stage of the British Pleistocene in and around its type area of the Central England. Quaternary Science Reviews 2, 261-280.

Straw, A., 1983. Pre-Devensian glaciation of Lincolnshire (Eastern England) and adjacent areas. Quaternary Science Reviews 2, 239-260.

West, R.G., Donner, J.J., 1956. The glaciations of East Anglia and the East Midlands: a differentiation based on stone orientation measurements of the tills. Quarterly Journal of the Geological Society of London 112, 146-184. 